\title{
PERANAN WANITA TANI DALAM PENERAPAN TEKNOLOGI BUDIDAYA SAYURAN DI LAHAN PASIR PANTAI KECAMATAN SANDEN KABUPATEN BANTUL
}

\author{
The Role of Women Farmers on The Application of Vegetables Cultivation Technology \\ in Sand Beach Land of Sanden Subdistrict of Bantul District
}

\author{
Siska Ernitawati, Roso Witjaksono, Harsoyo
}

\begin{abstract}
This research aimed to know the role of women farmers in the application of vegetables cultivation technology and the factors that affect the role of women farmers in the application of vegetables cultivation technology, and also determine the influence of the role of women farmers and other factors that influence the adoption of vegetables cultivation technology. Descriptive method with survey techniques is used in this research. Sampling villages and farmer groups conducted purposively, while sampling of women farmers were chosen by simple random sampling. Tatal sample amounted to 60 women farmers consist of 30 women farmers from the Manunggal farmer groups and 30 women farmers from the Pasir Makmur farmer groups. The proportion test and multiple linear regression test is the method analysis which is used. The results showed that the role of women farmers in the application of vegetables cultivation technology in the middle category, while the rate of adoption of vegetables cultivation technology is high. The age and knowledge gave positive influence on the role of women farmers, while education, women farmers activity in extension, attitude, motivation, family members, total of productive family members, family income, and the cultural value orientation did not significantly affect on the role of women farmers. The age, education, and women farmers activity in extension gave positive influence on the adoption of vegetables cultivation technology, while the role of women farmers, knowledge, attitude, motivation, family members, total of productive family members, family income, and the cultural value orientation did not significantly affect the adoption of vegetables cultivation technology
\end{abstract}

\section{Keywords: The role, women farmers, adoption, vegetables cultivation}

\section{INTISARI}

Penelitian ini bertujuan untuk mengetahui peranan wanita tani dalam penerapan teknologi budidaya sayuran dan faktor-faktor yang mempengaruhi, serta mengetahui pengaruh peranan wanita tani dan faktor lain terhadap adopsi teknologi budidaya sayuran. Metode yang digunakan dalam penelitian ini adalah metode deskriptif dengan teknik survei. Pengambilan sampel desa dan kelompok dilakukan secara purposif, sedangkan pengambilan sampel wanita tani dengan acak sederhana. Total sampel berjumlah 60 wanita tani yaitu 30 wanita tani dari Kelompok Tani Manunggal dan 30 wanita tani dari Kelompok Tani Pasir Makmur. Data dianalisis dengan uji proporsi dan analisis regresi linier berganda. Hasil penelitian menunjukkan bahwa tingkat peranan wanita tani dalam penerapan teknologi budidaya sayuran termasuk kategori sedang, sedangkan tingkat adopsi teknologi budidaya sayuran termasuk kategori tinggi. Umur dan pengetahuan berpengaruh positif terhadap peranan wanita tani, sedangkan pendidikan, keaktifan wanita tani dalam penyuluhan, sikap, motivasi, jumlah tanggungan keluarga, jumlah anggota keluarga berusia produktif, penghasilan keluarga, dan orientasi nilai budaya tidak berpengaruh nyata terhadap peranan wanita tani. Umur, pendidikan, dan keaktifan wanita tani dalam penyuluhan berpengaruh positif terhadap adopsi teknologi budidaya sayuran, sedangkan peranan wanita tani, pengetahuan, sikap, motivasi, jumlah tanggungan keluarga, jumlah anggota keluarga berusia produktif, penghasilan keluarga, dan orientasi nilai budaya tidak berpengaruh nyata terhadap adopsi teknologi budidaya sayuran

Kata kunci : Peranan, wanita tani, adopsi, budidaya sayuran

\section{PENDAHULUAN}

\section{Latar Belakang}

Kabupaten Bantul merupakan salah satu daerah di Yogyakarta yang dikenal sebagai daerah yang memiliki kawasan lahan pasir pantai yang potensial bagi pengembangan tanaman hortikultura khususnya tanaman sayuran. Budidaya tanaman sayuran dan buah merupakan salah satu jenis usaha budidaya tanaman yang pada awalnya bertujuan untuk memenuhi kebutuhan pangan dan gizi keluarga, namun seiring dengan meningkatkanya jumlah penduduk dan penghasilan masyarakat menyebabkan potensi pasar produk sayuran meningkat (Ashari, 1995). Untuk memenuhi kebutuhan pangan, maka diperlukan perhatian 
khusus dalam penggunaan lahan potensial tersebut melalui perbaikan teknologi budidaya. Diantaranya cara bercocok tanam, penggunaan varietas unggul, pemupukan, pengairan dan pengendalian hama merupakan unsur-unsur teknologi yang dapat meningkatkan produksi.

Pemanfaatan kawasan lahan pasir pantai untuk budidaya tanaman sayuran tidak terlepas dari adanya perkembangan teknologi. Hal ini karena kondisi lahan yang berbeda dengan lahan sawah sehingga dalam membudidayakan tanaman sayuran membutuhkan banyak perhatian serta curahan waktu tenaga kerja. Dalam melakukan budidaya sayuran diperlukan pemeliharaan yang intensif karena kondisi lahan pasir pantai yang membutuhkan perawatan khusus. Oleh karena itu, disamping peranan pria (bapak tani), peranan wanita tani juga diperlukan dalam budidaya sayuran di lahan pasir pantai.

\section{Tujuan}

1. Mengetahui peranan wanita tani dalam penerapan teknologi budidaya sayuran di lahan pasir pantai Kecamatan Sanden, Kabupaten Bantul.

2. Mengetahui faktor-faktor yang mempengaruhi peranan wanita tani dalam penerapan teknologi budidaya sayuran di lahan pasir pantai Kecamatan Sanden, Kabupaten Bantul.

3. Mengetahui pengaruh peranan wanita tani dan faktor-faktor yang mempengaruhi terhadap adopsi teknologi budidaya sayuran di lahan pasir pantai Kecamatan Sanden, Kabupaten Bantul.

\section{Tinjauan Pustaka}

\section{Wanita Tani}

Wanita tani adalah adalah sosok wanita atau istri petani yang terlibat secara langsung atau tidak langsung, muda atau dewasa/tua yang bertanggung jawab dalam kegiatan usaha tani atau kegiatan lainnya yang berhubungan dengan kehidupan dan peningkatan kesejahteraan rumah tangga petani (Elizabeth, 2008). Wanita sebagai sumber daya manusia dalam kegiatan pembangunan, perlu memiliki motivasi, pengetahuan, dan ketrampilan.

Dalam usaha mengikutsertakan wanita dalam kegiatan pembangunan pertanian, perlu ditunjang adanya pembagian kerja yang baik antara pria dan wanita dengan cara seperti pekerjaan-pekerjaan yang lebih banyak membutuhkan tenaga (kerja fisik) sebaiknya dilakukan oleh kaum pria dan pekerjaanpekerjaan yang lebih banyak membutuhkan ketelitian dilakukan oleh kaum wanita (Situmorang, 1988). Namun kecenderungan yang ada saat ini, hal tersebut tidak berlaku lagi dimana wanita juga banyak yang melakukan pekerjaan yang membutuhkan tenaga, dan banyak pula pria yang melakukan pekerjaan yang membutuhkan ketelitian.

\section{Peranan Wanita Tani}

Peranan wanita tani dalam budidaya sayuran mampu meringankan beban tugas bapak tani, dan juga secara tidak langsung ikut dalam meningkatkan pendapatan keluarga. Hal ini mengingat jumlah wanita yang cukup besar (hampir 50\% dari total jumlah penduduk) di Indonesia. Apabila tenaga kerja wanita dapat dilibatkan secara aktif dalam pembangunan pertanian, maka dapat meningkatkan pendapatan yang cukup besar khususnya dalam kegiatan produktif yang melibatkan peran serta dari wanita tani di pedesaan (Rusmini, 2007).

Dengan keikutsertaan wanita tani dalam mencari penghasilan rumah tangga akan memperkuat kedudukan wanita tani dalam rumah tangga karena wanita tani akan lebih leluasa dalam menentukan pengeluaran bagi keluarga, ikut terlibat dalam mengambil keputusan. Tazhan (1980) menyebutkan, keluarga petani merupakan suatu kesatuan produktif sehingga setiap keputusan yang diambil oleh petani dalam hubungannya dengan usaha taninya pada umumnya merupakan keputusan keluarga. Kadangkala pria lebih dominan tetapi kadangkala juga peranan wanita tani akan lebih dominan.

Suratiyah (1983) juga menyebutkan bahwa peranan pria dalam pengambilan keputusan teknis budidaya dalam hal pengolahan lahan sampai dengan panen biasanya didominasi oleh pria. Sedangkan peranan wanita tani hanya akan terlibat dalam kegiatan seperti penentuan pembagian bawon, proses hasil, penjualan hasil, dan penggunaan hasil atau pendapatan karena wanita tani yang lebih mengetahui berapa kebutuhan sehari-hari untuk keluarganya. Di daerah pantai pun penjualan hasil dan penggunaan hasil pendapatan juga didominasi oleh wanita tani. 


\section{Faktor-Faktor yang Mempengaruhi Peranan Wanita Tani}

a. Umur

Umur adalah satuan waktu, dimana manusia dikatakan berumur sekian tahun diukur sejak lahir hingga waktu umur itu dihitung. Menurut Suratiyah dan Hariadi (1990), umur berkaitan dengan partisipasi kerja wanita tani. Umur yang lebih tua akan lebih tinggi partisipasinya. Tingkat partisipasi dan keterlibatan wanita tani ini kemudian akan menurun secara bertahap pada umur 55 tahun.

\section{b. Pendidikan}

Wanita tani yang berpendidikan tinggi umumnya ingin menerapkan pengetahuannya terutama di masyarakat. Faktor pendidikan merupakan pendorong daripada perubahan, pendidikan juga dapat mempengaruhi sikap, kedudukan, pengambilan keputusan serta perilaku wanita tani. Tingkat pendidikan akan mewakili seberapa jauh tingkat pengetahuan wanita tani. Semakin tinggi jenjang yang dicapai, menunjukkan keyakinan bahwa teknologi baru akan menguntungkan bila diterapkan. Semakin tinggi pendidikan juga berpengaruh pada kemudahan wanita tani menerima teknologi dan menerapkan teknologi tersebut.

\section{c. Keaktifan dalam Penyuluhan}

Keaktifan dalam penyuluhan berkaitan dengan banyaknya waktu yang diluangkan oleh wanita tani untuk mengikuti kegiatan penyuluhan yang berkaitan dengan informasi budidaya dan perkembangan teknologi budidaya. Keaktifan dalam mengikuti kegiatan penyuluhan akan berpengaruh pada meningkatnya pengetahuan wanita tani karena sering memperoleh informasi yang berkaitan dengan teknis budidaya sayuran.

\section{d. Pengetahuan}

Tingkat pengetahuan akan mempengaruhi peranan wanita tani dalam melakukan teknis budidaya sayuran secara tepat. Melalui pengetahuan ini akan diketahui seberapa jauh wawasan yang telah dimiliki oleh wanita tani untuk ikut berperan dalam melakukan budidaya sayuran.

\section{e. Sikap}

Menurut Van den Ban dan Hawkins (1999) sikap didefinisikan sebagai perasaan, pikiran, dan kecenderungan seseorang yang kurang lebih bersifat permanen mengenai aspek-aspek tertentu dalam lingkungannya. Komponen-komponen sikap adalah pengetahuan, perasaan-perasaan, dan kecenderungan untuk bertindak. Sikap wanita tani akan berpengaruh dalam penerapan teknologi budidaya hortikultura. Apabila sikap wanita tani positif terhadap teknologi budidaya sayuran maka akan cenderung lebih mudah dalam mempraktekkan teknologi yang diberikan.

\section{f. Motivasi}

Motivasi adalah dorongan yang menyebabkan seseorang mau dan rela untuk mengerahkan kemampuan dalam bentuk keahlian dan ketrampilan, tenaga, dan waktunya untuk menyelenggarakan berbagai kegiatan yang menjadi tanggung jawabnya dan menunaikan kewajibanyya dalam rangka pencapaian tujuan dan berbagai sasaran organisasi yang telah ditentukan sebelumnya (Siagian, 2004).

Teori motivasi yang dikembangkan oleh Alderfer dalam Siagian (2004) yaitu teori ERG:

\section{1) Existence}

Mempertahankan eksistensi seseorang merupakan kebutuhan yang sangat mendasar. Mempertahankan eksistensi secara terhormat itu berarti antara lain terpenuhinya kebutuhan dasar. Bila menggunakan klasifikasi Maslow berarti terpenuhinya kebutuhan primer dan rasa aman.

\section{2) Relatedness}

Kebutuhan yang tercermin pada sifat dasar manusia sebagai insan sosial. Setiap orang ingin mengaitkan keberadaannya dengan orang lain dan dengan lingkungannya. Bila dibandingkan dengan klasifikasi Maslow kebutuhan relatedness identik dengan kebutuhan sosial dan esteem.

\section{3) Growth}

Kebutuhan yang pada dasarnya tercermin pada keinginan seseorang untuk tumbuh dan berkembang. Kebutuhan ini seperti dijelaskan Maslow diklasifikasikan sebagai aktualisasi diri.

Semakin tinggi motivasi wanita tani akan berpengaruh pada semakin tingginya keinginan dari wanita tani untuk menerapkan teknologi budidaya sayuran. Motivasi yang tinggi akan berpengaruh 
pada semakin tinggi teknologi yang mampu diterapkan oleh wanita tani untuk melakukan budidaya sayuran.

\section{g. Jumlah Tanggungan Keluarga}

Jumlah tanggungan keluarga menunjukkan seberapa banyak anggota keluarga yang ditanggung oleh keluarga petani. Semakin banyak anggota keluarga, terutama anak yang tidak bekerja menyebabkan kebutuhan keluarga petani akan semakin tinggi sehingga wanita tani dituntut bekerja membantu suami (bapak tani) guna meningkatkan pendapatan keluarga.

\section{h. Jumlah Anggota Keluarga Berusia Produktif}

Jumlah anggota keluarga berusia merupakan banyaknya anggota keluarga dalam rumah tangga petani yang telah berusia produktif sehingga mampu membantu pekerjaan rumah tangga dalam hal pekerjaan domestik seperti memasak, mencuci, membersihkan rumah, dan sebagainya sehingga peranan wanita tani yang biasanya lebih cenderung dicurahkan dalam kegiatan rumah tangga dapat dibantu oleh anggota keluarga lain. Semakin tingginya jumlah anggota keluarga berusia produktif dalam rumah tangga petani berdampak pada semakin tingginya peranan wanita tani dalam penerapan teknologi budidaya sayuran.

\section{i. Penghasilan Keluarga}

Penghasilan keluarga dapat mempengaruhi peranan wanita tani. Umumnya keluarga petani yang penghasilannya rendah akan mempengaruhi peranan wanita tani dalam peningkatan pendapatan keluarga. Suratiyah (1989), juga menyatakan bahwa kemiskinan merupakan salah satu penyebab utama wanita tani bekerja dalam kondisi apapun. Tingkat penghasilan keluarga akan berpengaruh dalam kontribusi wanita tani dalam penerapan teknologi budidaya sayuran. Tingkat penghasilan yang tinggi biasanya disebabkan karena keaktifan wanita tani dalam mencari nafkah untuk keluarga. Dalam hal ini keaktifannya dalam membantu suami (bapak tani) dalam kegiatan pertanian karena mata pencaharian utama sebagai petani.

\section{j. Orientasi Nilai Budaya}

Orientasi nilai budaya merupakan konsep yang hidup dalam pikiran masyarakat mengenai hal-hal yang dianggap bernilai dalam hidup. Nilai budaya berfungsi sebagai pedoman tertinggi bagi perilaku manusia, sebagai bagian dari adat istiadat serta wujud dari nilai kebudayaan. Menurut Kluckhohn, sistem nilai budaya dalam kebudayaan di dunia ini mengenai lima masalah pokok dalam kehidupan manusia yaitu :
a) Masalah mengenai hakekat dari hidup manusia
b) Masalah mengenai hakekat dari karya manusia
c) Masalah mengenai hakekat dari kedudukan manusia dalam ruang waktu
d) Masalah mengenai hakekat dari hubungan manusia dengan alam sekitarnya
e) Masalah mengenai hakekat dari hubungan manusia dengan sesamanya (Koentjaraningrat, 1981).

\section{Adopsi Teknologi}

Mardikanto (1996) mengemukakan proses adopsi pada hakikatnya diartikan sebagai proses perubahan perilaku baik yang berupa pengetahuan, sikap maupun keterampilan pada diri seseorang setelah menerima inovasi. Penerimaan di sini mengandung arti tidak sekedar tahu tetapi sampai benar-benar dapat melaksanakan atau menerapkan dengan benar serta menghayatinya dalam kehidupan dan usaha taninya.

Tahapan adopsi menurut Rogers cit Rusilawati (2005) cit Nugroho (2010) dimulai dari:

\section{a. Awareness (tahu dan sadar)}

Pada tahap ini petani sadar bahwa telah ada hal-hal baru yang belum bisa dilaksanakan. Hal ini terjadi karena ia berhubungan (berkomunikasi) dengan pihak lain seperti penyuluh, tetangan, family, dan lain-lain. Kesadaran dan pengetahuan tentang adanya hal-hal baru itu menimbulkan sikap dari diri petani, sikap acuh tak acuh atau sikap menarik perhatian terhadap hal baru tersebut.

\section{b. Interest (menaruh minat)}

Pada tahap ini, dari adanya perhatian petani dapat meningkatkan pada tahap menaruh minat terhadap hal-hal baru tersebut. minat ini biasanya timbul setelah early adopter menerapkan. Petani mulai bertanya-tanya, mereka ingin tahu lebih banyak mengenai hal itu. 


\section{c. Evaluation (penilaian)}

Petani mulai berpikir-pikir setelah mengetahui keterangan-keterangan lebih banyak, kemudian petani tersebut mempertimbangkan keterangan yang telah diterimanya. Mereka mengadakan perhitungan walau secara taksiran. Kalau sekiranya menguntungkan mereka akan mencobanya. Tahap penilaian ini, petani mempertimbangkan 3 aspek yaitu aspek sosial, ekonomi, dan aspek teknis.

\section{d. Trial (percobaan)}

Pada tahap ini, setelah petani yakin dan hilang keragu-raguannya mengenai manfaat dari hal baru tersebut, mereka mulai mencoba-coba melaksanakannya. Yang sering terjadi, pada tahap mencoba ini tidak dilakukan sendiri tetapi dengan cara melihat percobaan yang dilakukan orang lain atau demonstrasi dalam rangka kegiatan penyuluhan. Dalam hal ini terjadi peniruan, apabila petani lain berhasil dalam percobaannya, mereka akan lebih yakin dan mau penerapan. Apabila terjadi kegagalan, mereka untuk seterusnya sulit untuk mempercayai lagi. Oleh karena itu peranan penyuluh di sini sangat penting.

\section{e. Adoption (penerapan)}

Pada tahap ini, petani sudah yakin akan manfaat dari hal baru tersebut, untuk seterusnya petani tersebut akan melaksanakannya

\section{METODE PENELITIAN}

Metode dasar yang digunakan dalam penelitian ini adalah deskriptif. Penelitian deskriptif tertuju pada pemecahan masalah yang ada pada masa sekarang. Menurut Nawawi (2005), penelitian deskriptif merupakan suatu usaha mendeskripsikan pada tahap pemulaan tertuju pada usaha menemukan gejala-gejala secara lengkap di dalam aspek yang diselidiki, agar jelas keadaan dan kondisinya. Pada tahap metode deskriptif tidak lebih daripada penelitian yang bersifat menemukan fakta-fakta seadanya (fact finding).

Secara operasional penelitian ini juga dilakukan dengan metode penelitian survei. Survei akan dilakukan dengan kuisioner untuk berkomunikasi dengan responden-respondennya. Kuisioner digunakan dalam survei sebagai instrument komunikasi untuk menanyakan pertanyaan-pertanyaan dan mendapatkan jawabanjawaban dari responden.
Penelitian ini dilakukan di Kecamatan Sanden Kabupaten Bantul. Kecamatan Sanden merupakan kecamatan yang paling potensial untuk kegiatan budidaya sayuran di lahan pasir pantai. Sampel yang diambil meliputi sampel desa, sampel kelompok tani, dan sampel wanita tani

\section{Uji Hipotesis 1}

Untuk menguji hipotesis pertama tentang peranan wanita tani dalam penerapan teknologi budidaya sayuran di lahan pasir pantai maka diuji dengan menggunakan analisis uji proporsi dengan rumus sebagai berikut:

$$
\text { Zhit }=\frac{x / n-P o}{\sqrt{\frac{P o(1-P o)}{n}}} \quad, \alpha=10 \%
$$

Pengujian hipotesis:

HO $: P \leq 50 \%$

$\mathrm{Ha} \quad: \mathrm{P}>50 \%$

Dengan

H0 : Diduga kurang atau sama dengan $50 \%$ peranan wanita tani dalam penerapan teknologi budidaya sayuran memiliki kategori yang tinggi.

Ha : Diduga lebih dari 50\% peranan wanita tani dalam penerapan teknologi budidaya sayuran memiliki kategori yang tinggi.

\section{Uji Hipotesis 2}

Untuk mengetahui faktor-faktor yang mempengaruhi peranan wanita tani dalam penerapan teknologi budidaya sayuran di lahan pasir pantai adalah dengan menggunakan analisis linier berganda sehingga didapatkan persamaan regresi sebagai berikut:

$$
\begin{aligned}
Y= & A+b_{1} x_{1}+b_{2} x_{2}+b_{3} x_{3}+b_{4} x_{4}+b_{5} x_{5}+b_{6} x_{6}+ \\
& b_{7} x_{7}+b_{8} x_{8}+b_{9} x_{9}+b_{10} x_{10}
\end{aligned}
$$

\section{Keterangan :}

$\mathrm{Y}=$ Peranan wanita tani

$\mathrm{A}=$ Nilai konstanta

$b_{1}, b_{2}, b_{3}, \ldots \ldots \ldots . b_{10}=$ Koefisien regresi

$\mathrm{x}_{1}=$ Umur

$\mathrm{x}_{2}=$ Pendidikan

$x_{3}=$ Keaktifan dalam penyuluhan

$\mathbf{x}_{4}=$ Pengetahuan

$x_{5}=$ Sikap

$\mathrm{x}_{6}=$ Motivasi 
$\mathrm{x}_{7}=$ Jumlah tanggungan keluarga

$\mathrm{x}_{8}=$ Jumlah anggota keluarga yang berusia produktif

$x_{9}=$ Penghasilan keluarga

$\mathrm{x}_{10}=$ Orientasi nilai budaya (Dummy Variabel)

\section{Uji Hipotesis 3}

Untuk mengetahui pengaruh peranan wanita tani dan faktor-faktor lain terhadap adopsi teknologi budidaya sayuran di lahan pasir pantai digunakan analisis regresi linier berganda sehingga didapatkan persamaan regresi sebagai berikut:

$$
\begin{aligned}
Y= & A+b_{1} x_{1}+b_{2} x_{2}+b_{3} x_{3}+b_{4} x_{4}+b_{5} x_{5}+b_{6} x_{6}+ \\
& b_{7} x_{7}+b_{8} x_{8}+b_{9} x_{9}+b_{10} x_{10}+b_{11} x_{11}
\end{aligned}
$$

\section{Keterangan :}

$\mathrm{Y}=$ Adopsi teknologi

A = Nilai konstanta

$b_{1}, b_{2}, b_{3} \ldots . . b_{11}=$ Koefisien regresi

$\mathrm{x}_{1} \quad=$ Peranan wanita tani

$\mathrm{x}_{2}=$ Umur

$\mathrm{x}_{3}=$ Pendidikan

$\mathrm{x}_{4}=$ Keaktifan dalam Penyuluhan

$\mathrm{x}_{5} \quad=$ Pengetahuan

$\mathrm{x}_{6}=$ Sikap

$\mathrm{x}_{7} \quad=$ Motivasi

$\mathrm{x}_{8} \quad$ = Jumlah tanggungan keluarga

$\mathrm{x}_{9} \quad$ = Jumlah anggota keluarga yang berusia produktif

$\mathbf{x}_{10}=$ Penghasilan keluarga

$\mathbf{x}_{11}=$ Orientasi nilai budaya (Dummy Variabel)

\section{HASIL DAN PEMBAHASAN}

Tinggi rendahnya peranan wanita tani dalam penerapan teknologi budidaya sayuran di lahan pasir pantai dapat diketahui dengan uji proporsi. Pada hipotesis pertama, yaitu diduga lebih dari $50 \%$ wanita tani mempunyai peranan yang tinggi dalam penerapan teknologi budidaya sayuran. Untuk membuktikan kebenaran dan hipotesis, maka dilakukan perhitungan menggunakan uji proporsi.

Taraf signifikansi pada $\alpha=0,1(10 \%), n=60$, $x=5, P o=50 \%$

$$
\text { Zhit }=\frac{x / n-P_{o}}{\sqrt{\frac{P o(1-P o)}{n}}}
$$

$$
\begin{aligned}
& Z \text { hit }=\frac{5 / 60-0,5}{\sqrt{\frac{0,5(1-0,5)}{60}}} \\
& Z \text { hit }=\frac{-0,417}{0,064} \\
& Z \text { hit }=-6,516
\end{aligned}
$$

Kesimpulan

Dari data diperoleh kesimpulan :

$\mathrm{Z}$ hit $=-6,516$

$\mathrm{Z}$ tab $=1,645$

$\mathrm{Z}$ hitung $<\mathrm{Z}$ Tabel, maka Ho diterima dan $\mathrm{Ha}$ ditolak.

Berdasarkan hasil perhitungan menggunakan uji proporsi, diperoleh nilai $Z$ hitung sebesar -6,516. Hasil nilai uji proporsi lebih kecil dibandingkan dengan nilai $Z$ tabel yaitu 1,645 . Hal ini menunjukkan bahwa Ho diterima dan Ha ditolak, dimana kurang dari $(<50 \%)$ wanita tani di lahan pasir pantai Kecamatan Sanden memiliki peranan yang tinggi dalam penerapan teknologi budidaya sayuran di lahan pasir pantai Kecamatan Sanden Kabupaten Bantul.

Untuk mengetahui faktor-faktor yang mempengaruhi peranan wanita tani dalam penerapan teknologi budidaya sayuran di lahan pasir pantai digunakan analisis regresi linier berganda metode backward sehingga muncul hasil regresi (Model 9) pada Tabel 1.

Berdasarkan analisis regresi dapat diketahui bahwa nilai signifikansi variabel umur wanita tani sebesar 0,001 dan nilai signifikansi variabel pengetahuan wanita tani sebesar 0,057 . Kedua variabel tersebut memiliki nilai signifikansi lebih kecil dari taraf signifikansi $\alpha: 0,1$. Hal ini menunjukkan bahwa variabel umur wanita tani dan pengetahuan wanita tani berpengaruh nyata terhadap peranan wanita tani dalam penerapan teknologi budidaya sayuran. Dari hasil analisis regresi linier berganda juga diperoleh nilai $R$ sebesar 0,456 yang menunjukkan bahwa antara peranan wanita tani dalam penerapan teknologi budidaya sayuran (variabel dependen) dengan umur wanita tani, dan pengetahuan wanita tani (variabel independen) memiliki korelasi atau hubungan yang lemah karena nilai $\mathrm{R}$ kurang dari 0,5. 
Tabel 1. Hasil Analisis Regresi Linier Berganda Mengenai Faktor-faktor yang Diduga Mempengaruhi Peranan Wanita Tani dalam Penerapan Teknologi Budidaya Sayuran (Model 9)

\begin{tabular}{lrrrc}
\hline \multicolumn{1}{c}{ Variabel } & $\begin{array}{c}\text { Koefisien } \\
\text { Regresi }(\mathbf{B})\end{array}$ & t hitung & \multicolumn{1}{c}{ Sig } & Ket \\
\hline Umur $\left(\mathrm{X}_{1}\right)$ & 0,300 & 3,550 & 0,001 & $*$ \\
Pengetahuan $\left(\mathrm{X}_{4}\right)$ & 0,162 & 1,940 & 0,057 & $*$ \\
\hline Konstanta & -10.716 & & & \\
\hline $\mathrm{R}$ & 0,456 & & & \\
R square & 0,207 & & & \\
Adjusted square & 0,18 & & & \\
F hitung & 7,462 & & & \\
F Tabel & 2,398 & & & \\
\hline
\end{tabular}

Keterangan : * signifikansi pada taraf $10 \%$

Sumber : Analisis Data Primer Tahun 2014

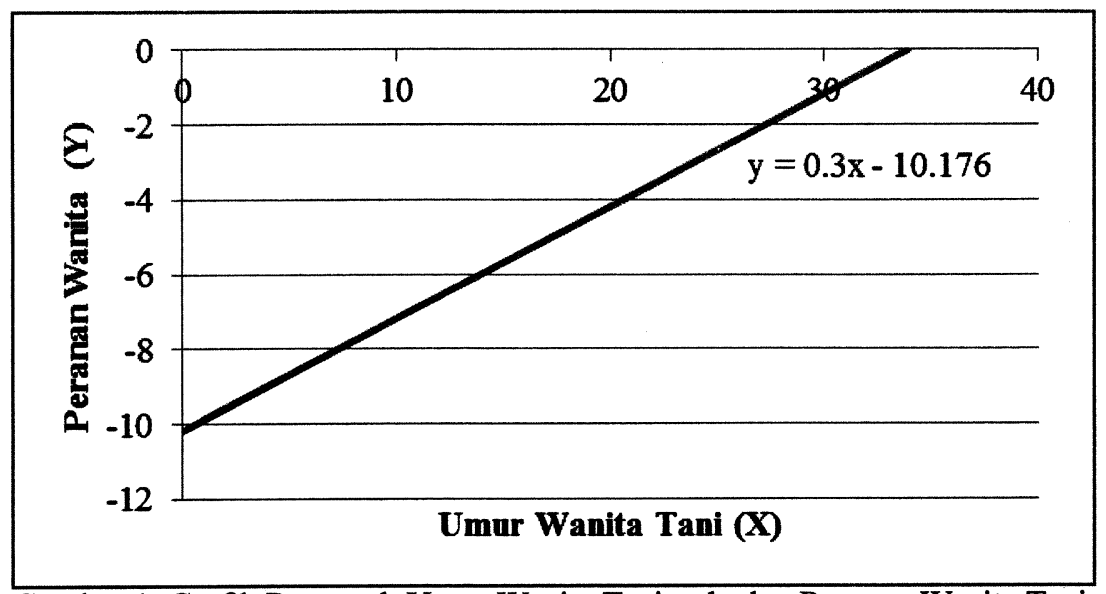

Gambar 1. Grafik Pengaruh Umur Wanita Tani terhadap Peranan Wanita Tani dalam Penerapan Teknologi Budidaya Sayuran

\section{Umur}

Umur wanita tani merupakan salah satu variabel yang mempengaruhi peranan wanita tani dalam penerapan teknologi budidaya sayuran. Hasil analisis regresi (Model 9) menunjukkan bahwa nilai signifikansi variabel umur wanita tani sebesar 0,001 lebih kecil daripada taraf signifikansi $\alpha: 0,1$ dengan nilai $t$ hitung sebesar 3,550 dan $t$ tabel sebesar 1,671, $\mathrm{t}$ hitung $>\mathrm{t}$ tabel. Hal tersebut menunjukkan bahwa hipotesis diterima yang artinya umur wanita tani berpengaruh nyata terhadap peranan wanita tani dalam penerapan teknologi budidaya sayuran di lahan pasir pantai Kecamatan Sanden Kabupaten Bantul.

Berdasarkan hasil analisis regresi Tabel 1. diperoleh persamaan regresi sebagai berikut :

$$
Y=-10,176+0,300 X_{1}
$$

$$
\begin{aligned}
& \text { Keterangan: } \\
& \mathrm{Y}=\text { Peranan Wanita Tani } \\
& \mathrm{X}_{1}=\text { Umur Wanita Tani }
\end{aligned}
$$

Persamaan regresi linier pengaruh variabel umur wanita tani terhadap peranan wanita tani jika disajikan dalam bentuk grafik adalah sebagai berikut:

Berdasarkan Gambar 1. dapat diketahui koefisien regresi variabel umur wanita tani berpengaruh positif $(+)$ terhadap peranan wanita tani. Tanda positif $(+)$ pada nilai koefisien regresi menunjukkan bahwa arah hubungan antara variabel umur wanita tani dan variabel peranan wanita tani adalah searah. Berdasarkan persamaan tersebut nilai konstanta sebesar $-10,176$. Nilai koefisien regresi sebesar 0,300 menunjukkan bahwa setiap penambahan satu satuan variabel umur wanita tani $\left(X_{1}\right)$ akan meningkatkan nilai variabel peranan wanita tani (Y) sebesar 0,300. Dengan demikian, dapat disimpulkan bahwa hipotesis diterima, semakin tua umur wanita tani, maka semakin tinggi peranan wanita tani dalam penerapan teknologi budidaya sayuran. 


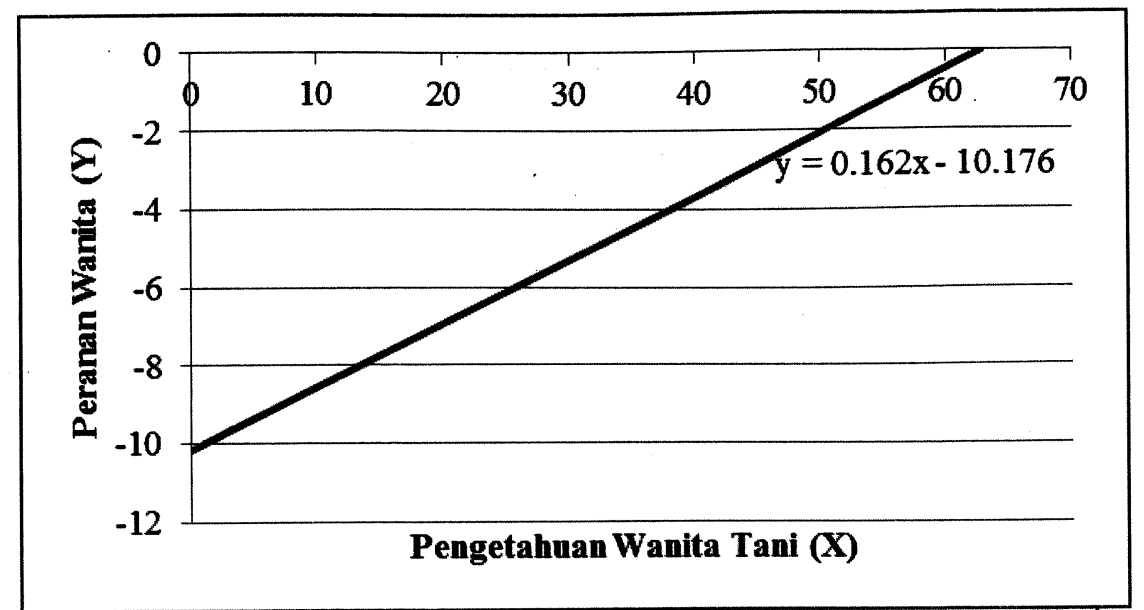

Gambar 2. Grafik Pengaruh Pengetahuan Wanita Tani terhadap Peranan Wanita Tani dalam Penerapan Teknologi Budidaya Sayuran

Tabel 2. Hasil Analisis Regresi Linier Berganda Mengenai Faktor-Faktor yang Diduga Mempengaruhi Adopsi Teknologi Budidaya Sayuran (Model 9)

\begin{tabular}{lrrrc}
\hline \multicolumn{1}{c}{ Variabel } & $\begin{array}{r}\text { Koefisien Regresi } \\
(B)\end{array}$ & t hitung & Sig & Ket \\
\hline Umur $\left(\mathrm{X}_{2}\right)$ & 0,224 & 2,368 & 0,021 & $*$ \\
Pendidikan $\left(\mathrm{X}_{3}\right)$ & 0,790 & 1,791 & 0,079 & $*$ \\
Keaktifan dalam Penyuluhan $\left(\mathrm{X}_{4}\right)$ & 0,432 & 2,576 & 0,013 & $*$ \\
\hline Konstanta & 35,303 & & & \\
\hline R & 0,425 & & & \\
R square & 0,181 & & & \\
Adjusted square & 0,137 & & & \\
F hitung & 4,121 & & & \\
F Tabel & 2,184 & & & \\
\hline
\end{tabular}

Keterangan : *signifikansi pada taraf $10 \%$

Sumber : Analisis Data Primer Tahun 2014

\section{Pengetahuan}

Pengetahuan wanita tani merupakan sejauh mana wawasan yang telah dimiliki oleh wanita tani untuk ikut terlibat dalam budidaya sayuran. Dengan adanya pengetahuan ini wanita tani akan membantu dalam budidaya tanaman sayuran di lahan pasir pantai. Hasil analisis regresi (Model 9) menunjukkan bahwa nilai signifikansi variabel pengetahuan wanita tani sebesar 0,057 lebih kecil dari taraf signifikansi $\alpha: 0,1$ dengan nilai thitung sebesar 1,940 dan nilai $t$ tabel sebesar $1,671, t$ hitung $>t$ tabel. Hal tersebut menunjukkan bahwa hipotesis diterima yang artinya pengetahuan wanita tani berpengaruh nyata terhadap peranan wanita tani dalam penerapan teknologi budidaya sayuran di lahan pasir pantai Kecamatan Sanden Kabupaten Bantul.

Berdasarkan hasil analisis regresi Tabel 1. diperoleh persamaan regresi sebagai berikut:

$$
Y=-10,176+0,162 X_{4}
$$

Keterangan :

$\mathrm{Y}=$ Peranan Wanita Tani

$\mathrm{X}_{4} \quad=$ Pengetahuan Wanita Tani

Berdasarkan Gambar 2. dapat diketahui koefisien regresi variabel pengetahuan wanita tani berpengaruh positif $(+)$ terhadap peranan wanita tani. Tanda positif $(+)$ pada nilai koefisien regresi menunjukkan bahwa arah hubungan antara variabel pengetahuan wanita tani dan variabel peranan wanita tani adalah searah. Berdasarkan persamaan tersebut nilai konstanta sebesar $-10,176$. Nilai koefisien regresi sebesar 0,162 menunjukkan bahwa setiap penambahan satu satuan variabel pengetahuan wanita tani $\left(\mathrm{X}_{4}\right)$ akan meningkatkan nilai variabel peranan wanita tani $(Y)$ sebesar 0,162 . Dengan demikian, dapat disimpulkan bahwa hipotesis 
diterima, semakin tinggi pengetahuan wanita tani, maka semakin tinggi peranan wanita tani dalam penerapan teknologi budidaya sayuran.

Untuk mengetahui faktor-faktor yang mempengaruhi adopsi teknologi dapat dilihat hasil analisis regresi berganda dengan metode Backward (Model 9) pada Tabel 2.

Berdasarkan analisis regresi 2 dapat diketahui bahwa nilai signifikansi variabel umur wanita tani sebesar 0,021 , pendidikan wanita tani sebesar 0,079 , dan keaktifan dalam penyuluhan memiliki nilai signifikansi 0,013 . Ketiga variabel tersebut memiliki nilai signifikansi lebih kecil dari taraf signifikansi $\alpha: 0,1$. Hal ini menunjukkan bahwa variabel umur wanita tani $\left(\mathrm{X}_{2}\right)$, pendidikan wanita tani $\left(\mathrm{X}_{3}\right)$, dan keaktifan dalam penyuluhan $\left(\mathrm{X}_{4}\right)$ berpengaruh nyata terhadap adopsi teknologi budidaya sayuran di lahan pasir pantai Kecamatan Sanden Kabupaten Bantul. Dari hasil analisis regresi linier berganda juga diperoleh nilai $R$ sebesar 0,425 yang menunjukkan bahwa antara adopsi teknologi budidaya sayuran (variabel dependen) dengan umur wanita tani, pendidikan wanita tani, dan keaktifan dalam penyuluhan (variabel independen) memiliki korelasi atau hubungan yang lemah karena nilai $R$ kurang dari 0,5 .

\section{Umur}

Umur wanita tani merupakan salah satu variabel yang mempengaruhi adopsi teknologi budidaya sayuran. Umur wanita tani yang berusia tua akan lebih tinggi tingkat adopsi teknologinya apabila dibandingkan dengan wanita tani yang berusia muda. Hasil analisis regresi (Model 9) menunjukkan bahwa nilai signifikansi variabel umur wanita tani sebesar 0,021 lebih kecil daripada taraf signifikansi $\alpha: 0,1$ dengan nilai t hitung sebesar 2,368 dan nilai $\mathrm{t}$ tabel sebesar 1,671 , $\mathrm{t}$ hitung $>\mathrm{t}$ tabel. Hal tersebut menunjukkan bahwa hipotesis diterima yang artinya umur wanita tani berpengaruh nyata terhadap adopsi teknologi budidaya sayuran di lahan pasir pantai Kecamatan Sanden Kabupaten Bantul.

Berdasarkan hasil analisis regresi Tabel 2. diperoleh persamaan regresi sebagai berikut :

$$
Y=35,303+0,224 X_{2}
$$

\section{Keterangan :}

$\mathrm{Y}=$ Adopsi Teknologi

$\mathrm{X}_{2}=$ Umur Wanita Tani

Berdasarkan Gambar 3. dapat diketahui koefisien regresi variabel umur wanita tani berpengaruh positif $(+)$ terhadap adopsi teknologi. Tanda positif $(+)$ pada nilai koefisien regresi menunjukkan bahwa arah hubungan antara variabel umur wanita tani dan variabel adopsi teknologi budidaya sayuran adalah searah. Berdasarkan persamaan regresi nilai konstanta sebesar 35,303. Apabila tidak ada pengaruh dari variabel umur wanita tani $(\mathrm{X}=0)$ maka nilai adopsi teknologi budidaya sayuran sebesar 35,303 . Nilai koefisien regresi sebesar 0,224 menunjukkan bahwa setiap penambahan satu satuan variabel umur wanita tani (X) akan meningkatkan nilai variabel adopsi teknologi (Y) sebesar 0,224. Dengan demikian, dapat disimpulkan bahwa hipotesis diterima, semakin tua umur wanita tani, maka semakin tinggi tingkat adopsi teknologi budidaya sayuran.

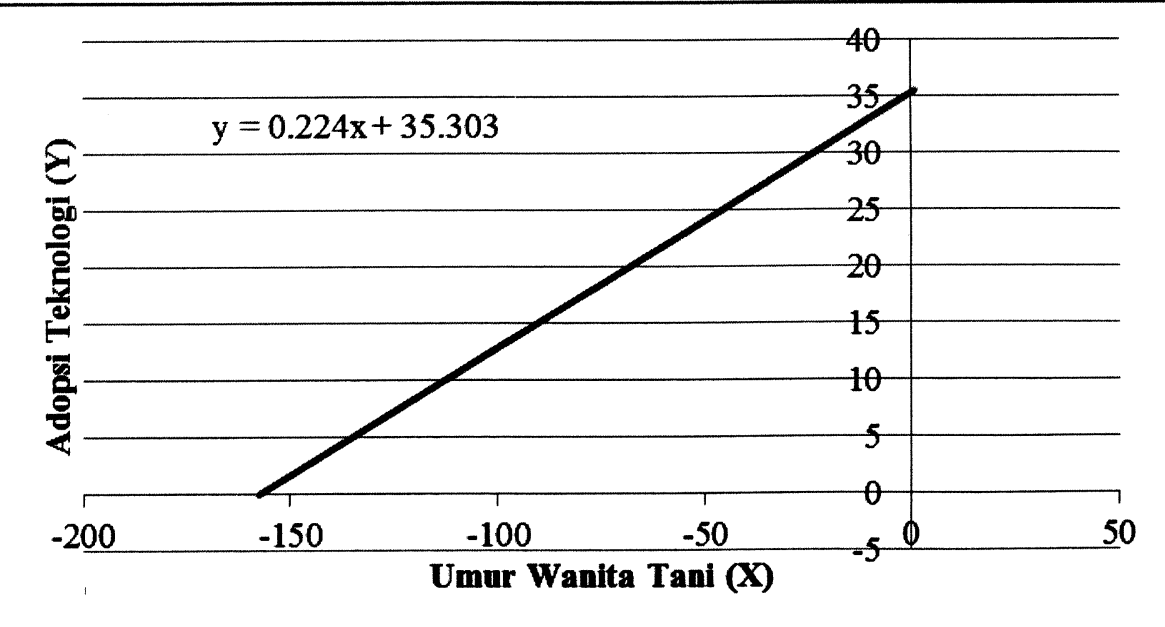

Gambar 3. Grafik Pengaruh Umur Wanita Tani terhadap Adopsi Teknologi 


\section{Pendidikan}

Pendidikan wanita tani merupakan pendidikan formal yang telah ditempuh wanita tani (SD, SMP, SMA, dan Perguruan Tinggi) yang diukur dengan jumlah tahun sampai penelitian ini dilaksanakan, melalui tingkat pendidikan ini akan berpengaruh terhadap tingkat adopsi teknologi budidaya sayuran. Hasil analisis regresi (Model 9) menunjukkan bahwa nilai signifikansi variabel pendidikan wanita tani sebesar 0,079 lebih kecil dari taraf signifikansi $\alpha: 0,1$ dengan nilai thitung sebesar 1,791 dan nilai $t$ tabel sebesar 1,671 , thitung $>t$ tabel. Hal tersebut menunjukkan bahwa hipotesis diterima yang artinya pendidikan wanita tani berpengaruh nyata terhadap adopsi teknologi budidaya sayuran di lahan pasir pantai Kecamatan Sanden Kabupaten Bantul.

Berdasarkan hasil analisis regresi Tabel 2 diperoleh persamaan regresi sebagai berikut :

$$
Y=35,303+0,790 X_{3}
$$

Keterangan :

$\mathrm{Y}=$ Adopsi Teknologi

$\mathrm{X}_{3}=$ Pendidikan Wanita Tani

Berdasarkan Gambar 4 dapat diketahui koefisien regresi variabel pendidikan wanita tani berpengaruh positif $(+)$ terhadap adopsi teknologi. Tanda positif $(+)$ pada nilai koefisien regresi menunjukkan bahwa arah hubungan antara variabel pendidikan wanita tani dan variabel adopsi teknologi budidaya sayuran adalah searah.

Berdasarkan persamaan regresi nilai konstanta sebesar 35,303. Apabila tidak ada pengaruh dari variabel pendidikan wanita tani $(\mathrm{X}=0)$ maka nilai adopsi teknologi sebesar 35,303. Nilai koefisien regresi sebesar 0,79 menunjukkan bahwa setiap penambahan satu satuan variabel pendidikan wanita tani (X) akan meningkatkan nilai variabel adopsi teknologi $(Y)$ sebesar 0,79. Dengan demikian, dapat disimpulkan bahwa hipotesis diterima, semakin tinggi tingkat pendidikan wanita tani, maka semakin tinggi tingkat adopsi teknologi budidaya sayuran.

\section{Keaktifan dalam Penyuluhan}

Keaktifan dalam penyuluhan merupakan keaktifan wanita tani mengikuti kegiatan penyuluhan yang dilakukan oleh kelompok tani. Melalui keaktifan yang tinggi dalam penyuluhan, informasi mengenai adopsi teknologi budidaya sayuran akan lebih banyak diterima. Hasil analisis regresi (Model 9) menunjukkan bahwa nilai signifikansi variabel keaktifan dalam penyuluhan sebesar 0,013 lebih kecil dari taraf signifikansi $\alpha: 0,1$ dengan nilai t hitung sebesar 2,576 dan nilai t tabel sebesar 1,671, thitung $>$ t tabel. Hal tersebut menunjukkan bahwa hipotesis diterima yang artinya keaktifan wanita tani dalam penyuluhan berpengaruh nyata terhadap adopsi teknologi budidaya sayuran di lahan pasir pantai Kecamatan Sanden Kabupaten Bantul.

Berdasarkan hasil analisis regresi Tabel 2. diperoleh persamaan regresi sebagai berikut :

$$
Y=35,303+0,432 X_{4}
$$

Keterangan :

$\mathrm{Y} \quad=$ Adopsi Teknologi

$\mathrm{X}_{4}=$ Keaktifan dalam Penyuluhan

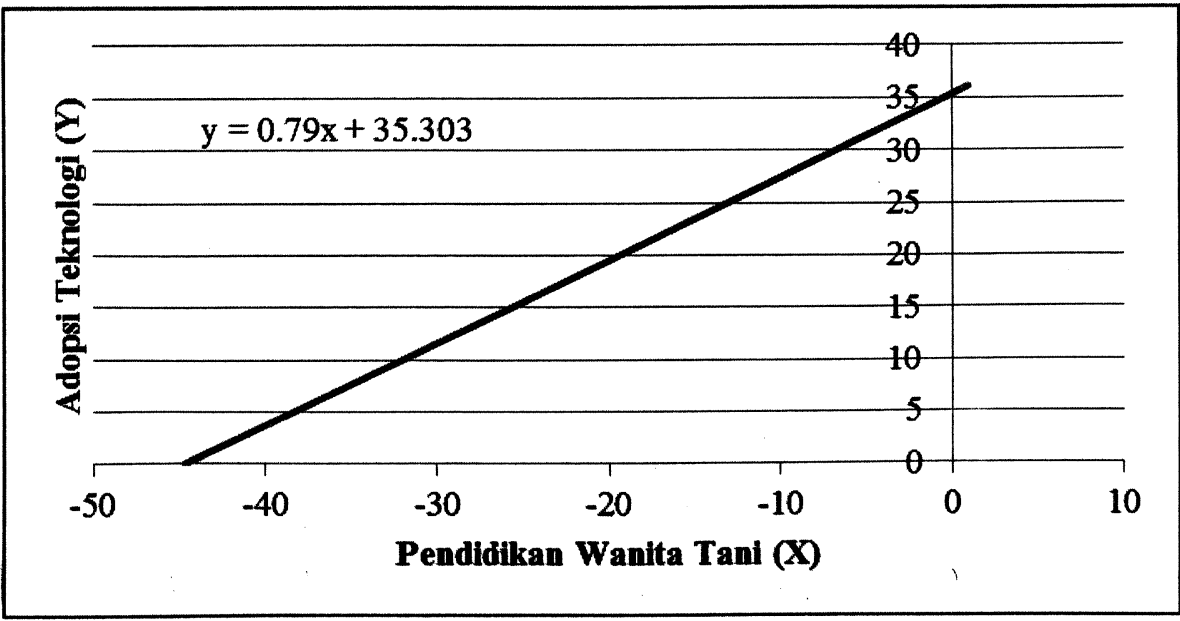

Gambar 4. Grafik Pengaruh Pendidikan Wanita Tani terhadap Adopsi Teknologi 


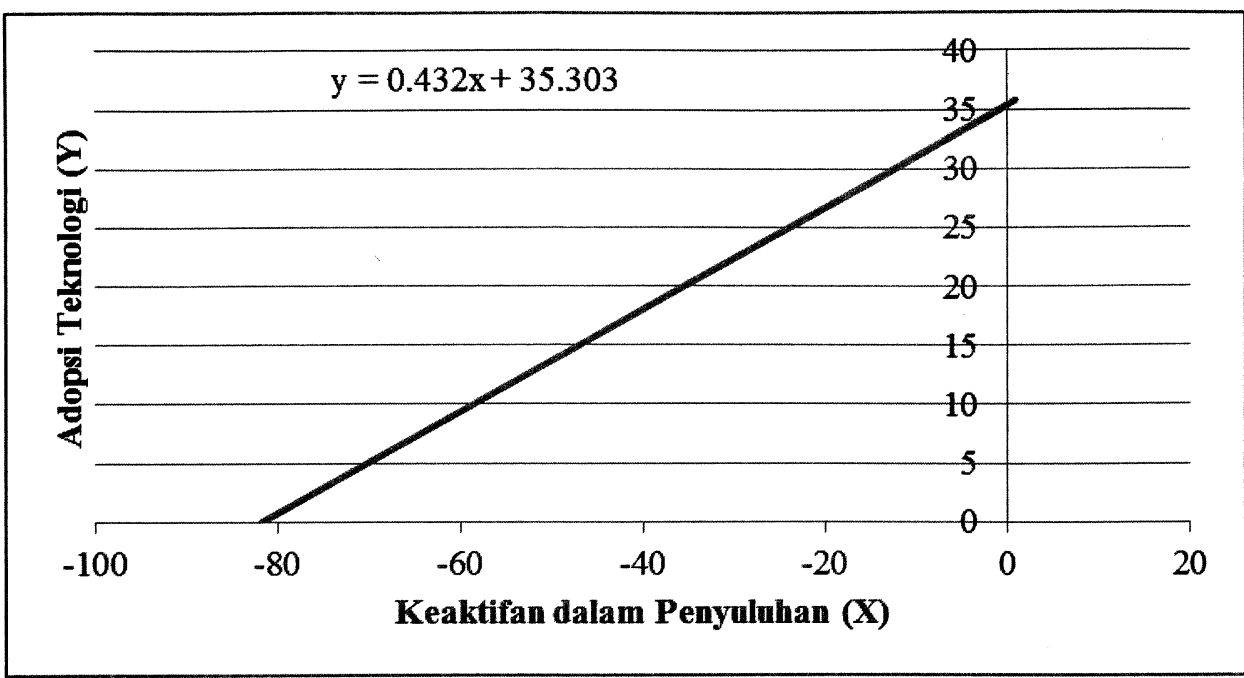

Gambar 5. Grafik Pengaruh Keaktifan dalam Penyuluhan terhadap Adopsi Teknologi

Berdasarkan Gambar 5. dapat diketahui koefisien regresi variabel keaktifan dalam penyuluhan berpengaruh positif $(+)$ terhadap adopsi teknologi. Tanda positif $(+)$ pada nilai koefisien regresi menunjukkan bahwa arah hubungan antara variabel keatifan dalam penyuluhan dan variabel adopsi teknologi budidaya sayuran adalah searah. Berdasarkan persamaan regresi nilai konstanta sebesar 35,303. Apabila tidak ada pengaruh dari variabel keaktifan dalam penyuluhan $(X=0)$ maka nilai adopsi teknologi sebesar 35,303. Nilai koefisien regresi sebesar 0,432 menunjukkan bahwa setiap penambahan satu satuan variabel keaktifan dalam penyuluhan $(\mathrm{X})$ akan meningkatkan nilai variabel adopsi teknologi (Y) sebesar 0,432. Dengan demikian, dapat disimpulkan bahwa hipotesis diterima, semakin aktif wanita tani dalam kegiatan penyuluhan, maka semakin tinggi tingkat adopsi teknologi budidaya sayuran.

\section{KESIMPULAN}

1. Peranan wanita tani sebesar $53,33 \%$ sehingga termasuk dalam kategori sedang dalam penerapan teknologi budidaya sayuran di lahan pasir pantai Kecamatan Sanden Kabupaten Bantul.

2. Faktor-faktor yang berpengaruh nyata terhadap peranan wanita tani dalam penerapan teknologi budidaya sayuran adalah umur dan pengetahuan.

a. Semakin tua umur wanita tani, maka semakin tinggi peranan wanita tani dalam penerapan teknologi budidaya sayuran. b. Semakin tinggi pengetahuan wanita tani, maka semakin tinggi peranan wanita tani dalam penerapan teknologi budidaya sayuran.

3. Faktor-faktor yang tidak berpengaruh nyata terhadap peranan wanita tani dalam penerapan teknologi budidaya sayuran adalah pendidikan, keaktifan dalam penyuluhan, sikap, motivasi, jumlah tanggungan keluarga, jumlah anggota keluarga berusia produktif, penghasilan keluarga, dan orientasi nilai budaya.

4. Tingkat adopsi teknologi budidaya sayuran di lahan pasir pantai sebesar 95\% sehingga termasuk dalam kategori tinggi.

5. Faktor-faktor yang berpengaruh nyata terhadap adopsi teknologi budidaya sayuran adalah umur, pendidikan, dan keaktifan dalam penyuluhan.

a. Semakin tua umur wanita tani, maka semakin tinggi tingkat adopsi teknologi budidaya sayuran.

b. Semakin tinggi tingkat pendidikan wanita tani, maka semakin tinggi tingkat adopsi teknologi budidaya sayuran.

c. Semakin aktif wanita tani dalam kegiatan penyuluhan, maka semakin tinggi tingkat adopsi teknologi budidaya sayuran.

6. Faktor-faktor yang tidak berpengaruh nyata terhadap adopsi teknologi budidaya sayuran adalah peranan wanita tani, pengetahuan, sikap, motivasi, jumlah tanggungan keluarga, jumlah anggota keluarga berusia produktif, penghasilan keluarga, dan orientasi nilai budaya.

7. Peranan wanita tani dalam penerapan teknologi budidaya sayuran di lahan pasir pantai banyak 
didominasi pada kegiatan yang membutuhkan ketelitian, kerumitan, serta tidak membutuhkan curahan tenaga seperti penanaman, penyiangan, panen, dan pasca panen, sedangkan pria (bapak tani) dominan pada kegiatan yang membutuhkan tenaga, pengetahuan, serta mudah untuk dilakukan seperti pengelolaan lahan, pemupukan, pengairan, dan pengendalian hama penyakit.

8. Peranan wanita tani sedang dalam penerapan teknologi budidaya sayuran karena curahan waktu wanita tani banyak dihabiskan untuk menyelesaikan tugas dalam sektor domestik (pekerjaan rumah tangga) sehingga dalam budidaya sayuran wanita tani hanya terlibat dalam kegiatan teknis yang membutuhkan tenaga ringan.

9. Peranan wanita tani tidak mempengaruhi adopsi teknologi budidaya sayuran karena dalam melakukan budidaya sayuran di lahan pasir pantai dilakukan secara bersama-sama antara wanita tani dengan pria (bapak tani) sehingga keputusan dalam melakukan adopsi teknologi banyak didominasi oleh pria (bapak tani) karena pelaku utama budidaya sayuran adalah pria (bapak tani).

\section{SARAN}

1. Untuk meningkatkan peranan wanita tani dalam penerapan teknologi budidaya sayuran seharusnya pengetahuan wanita tani tentang cara berbudidaya ditingkatkan dengan cara menjalin kerjasama dengan Penyuluh, Dinas Pertanian, dan BPTP untuk menyediakan informasi berkaitan dengan teknologi budidaya sayuran yang lebih lengkap sesuai kebutuhan wanita tani serta mudah dipahami dan mudah diterapkan.

2. Untuk meningkatkan peranan wanita tani dalam penerapan teknologi budidaya sayuran seharusnya adanya peranan yang saling mengisi di dalam rumah tangga antara anggota keluarga petani dengan wanita tani untuk menyelesaikan pekerjaan didalam rumah tangga sehingga curahan waktu wanita tani tidak hanya dihabiskan untuk mengurusi urusan rumah tangga sehingga keterlibatan wanita tani dalam kegiatan budidaya sayuran dapat lebih maksimal.

3. Untuk meningkatkan adopsi teknologi budidaya sayuran seharusnya keaktifan wanita tani dalam penyuluhan ditingkatkan. Hal ini dilakukan dengan mengupayakan adanya keterlibatan wanita tani dalam kegiatan penyuluhan yang dilakukan oleh kelompok tani. Adanya keterlibatan wanita tani dalam kegiatan penyuluhan dapat membantu pria (bapak tani) dalam mengadopsi teknologi budidaya sayuran karena fakta menunjukkan bahwa jarang pria (bapak tani) mentransfer informasi berkaitan teknologi budidaya secara langsung kepada wanita tani. Dengan adanya keterlibatan wanita tani dalam kegiatan penyuluhan maka informasi tentang teknologi budidaya sayuran tidak hanya diadopsi oleh pria (bapak tani) namun juga oleh keluarga petani.

\section{DAFTAR PUSTAKA}

Ashari, S. 1995. Hortikultura. Aspek Budidaya. Penerbit UI Press. Jakarta.

Elizabeth, R. 2008. Peran ganda wanita tani dalam mencapai ketahanan pangan rumah tangga di pedesaan. Jurnal IPTEK Tanaman Pangan Vol $3: 59-68$.

Hariadi, S.S., dan Ken Suratiyah. 1990. Wanita, Kerja, dan Rumah Tangga Pengaruh Pembangunan Pertanian Terhadap Peranan Wanita Pedesaan di DIY. Pusat Penelitian Kependudukan. Universitas Gadjah Mada. Yogyakarta.

Koentjaraningrat. 1981. Kebudayaan, Mentalitas dan Pembangunan. PT Gramedia. Jakarta.

Mardikanto. 1996. Penyuluhan Pembangunan Kehutanan. Departemen Kehutanan. Jakarta.

Nawawi, H. 2005. Metode Penelitian Bidang Sosial. Universitas Gadjah Mada. Yogyakarta.

Nugroho, Fajar P. 2010. Peran Penyuluh Pertanian dalam Adopsi Budidaya Padi Sawah di Kecamatan Sragen Kabupaten Sragen. Fakultas Pertanian. Universitas Gadjah Mada. Skripsi.

Rusmini, 2007. Partisipasi Wanita Tani dalam Pelaksanaan Pengelolaan Hama Terpadu (PHT) pada Tanaman Hortikultura di Kabupaten Donggala. Jurnal Agribisnis Vol 8(1) : 1-8

Siagian, S. P. 2004. Teori Motivasi dan Aplikasinya. Rineka Cipta. Jakarta.

Situmorang, V. 1988. Kedudukan Wanita di Mata Hukum. Bina Aksara. Jakarta.

Suratiyah cit Oppong dan Catie Chruch. 1989. Peranan Wanita dalam Pembangunan. Studi Tentang Kader Kesehatan Wanita di Kecamatan 
Naggulan Kabupaten Kulonprogo Yogyakarta.

Fakultas Pertanian. Universitas Gadjah Mada.

Yohyakarta.

Suratiyah, Ken. 1983. Peranan Wanita dalam

Penghasilan Keluarga Petani. Fakultas Pasca

Sarjana. Universitas Gadjah Mada. Tesis.
Tazhan, Hamdana Arief. 1980. Peranan Wanita Pedesaan (Curahan Tenaga Kerja Wanita Pedesaan). Paper Lokakarya Nasional Peranan Wanita dalam Pembangunan Pedesaan. Bogor Van den Ban, A. W. dan Hawkins. 1999. Penyuluhan Pertanian. Kanisius. Yogyakarta. 